CHAPTER 12

\title{
Climate Change Effects on Insects Implications for Crop Protection and Food Security
}

\author{
Hari C. Sharma
}

\section{CONTENTS}

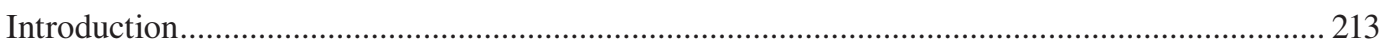

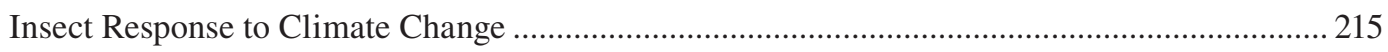

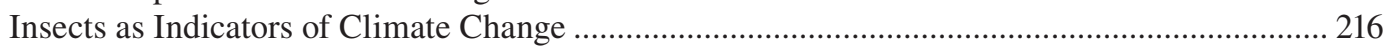

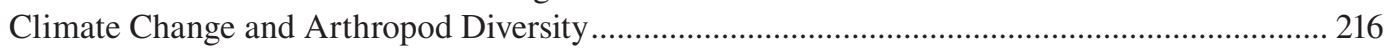

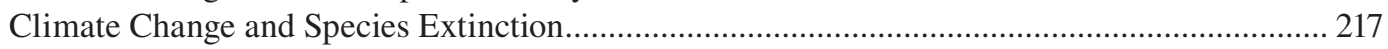

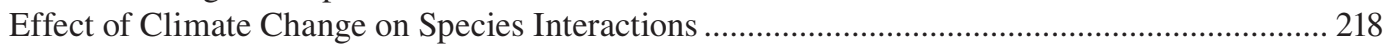

Impact of Climate Change on Geographic Distribution of Insect Pests........................................ 218

Evolutionary Changes and Emerging Pest Problems................................................................... 219

Impact of Climate Change on the Biology and Population Dynamics of Insect Pests..................220

Effect of Climate Change on the Activity and Abundance of Insect Pollinators.......................... 221

Effect of Climate Change on Pest Management and Food Security .............................................222

x xpression of Host Plant Resistance to Insect Pests .........................................................................22

x xpression of Resistance to Insects in Transgenic Crops............................................................225

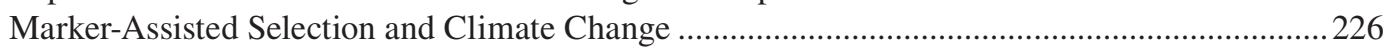

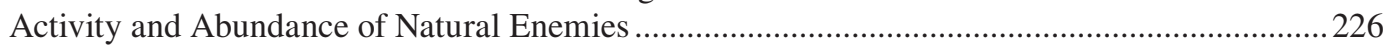

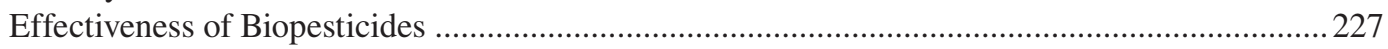

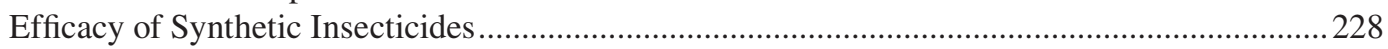

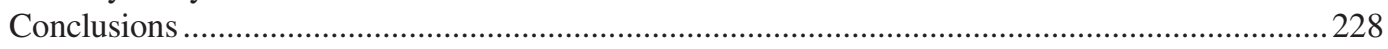

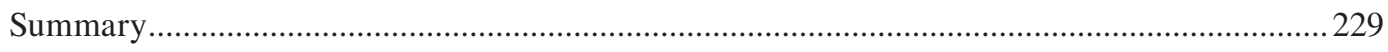

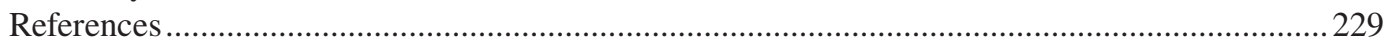

\section{INTRODUCTION}

Current estimates of changes in climate indicate an increase in global mean annual temperatures of $1^{\circ} \mathrm{C}$ by 2025 and $3^{\circ} \mathrm{C}$ by the end of the twenty-first century. The amounts of $\mathrm{CO}_{2}$ will double between 2025 and 2070, depending on the level of emission of greenhouse gasses (UNFCCC, 2007). Mean annual temperature changes between $3^{\circ} \mathrm{C}$ and $6^{\circ} \mathrm{C}$ are estimated to occur 
across Europe, with the greatest increases occurring at high latitudes. Global warming and climate change will have major implications for ecosystem services, water availability, crop production, and food security. Increased temperatures have drastically affected rice (Oryza sativa L.) production because of reduced crop duration in Philippines ( $10 \%$ reduction in rice yield per $1{ }^{\circ} \mathrm{C}$ rise in temperature) (Peng et al., 2004). An increase of $6^{\circ} \mathrm{C}$ in temperature and a precipitation deficit of $300 \mathrm{~mm}$ reduced maize (Zea mays L.) yield by $36 \%$ in the European Union (Ciais et al., 2005). Crop plants used as food by human beings are damaged by over 10,000 species of insects, which cause an estimated annual crop loss of $13.6 \%$ globally (Benedict, 2003). In India, the average annual losses caused by insect pests have been estimated to be $17.5 \%$ (valued at US $\$ 17.28$ billion) in eight major field crops, including cotton (Gossypium spp.), rice, maize, sugarcane (Saccharum spp.), rapeseed-mustard (Brassica spp.), groundnut (Arachis hypogeat L.), pulses, coarse cereals, and wheat (Triticum aestivum L.) (Dhaliwal et al., 2004, 2010). Losses attributable to insect damage are likely to increase as a result of decreased crop diversity and increased incidence of insect pests resulting from global warming.

The world population will increase by $25 \%$ to 7.5 billion by 2020 , and nearly 73 million people are added annually, of which 97\% live in developing countries (Pinstrup-Andersen and Cohen, 2000) (Figure 12.1). The amount of land available for crop production continues to decrease, and the trend is expected to be much more dramatic in developing than in developed countries. The decrease in the amount of land available for crop production will have major implications for food security in the future. The situation will become more serious with impending shifts in fauna and flora associated with climate change. Therefore, there is a need to focus on technologies that will help in increasing crop productivity on the available arable lands with minimum adverse effects on the environment. There has been a remarkable increase in total grain production between 1950 and 1980, but only a marginal increase in grain production was realized after the 1990s (Myers, 1999) (Figure 12.2). Much of the increase in grain production resulted from an increase in area under cultivation, irrigation, better agronomic practices, pest management, and improved cultivars.

AU: Please confirm the deletion of "and" h Yields of several crops have already reached a plateau in developed countries, and therefore much of the productivity gains in the future will have to be achieved through crop improvement, better use of natural resources, pest management, and improved productivity in developing countries. Productivity gains are essential for long-term economic growth; but in the short term, these are even more important for maintaining adequate food supplies for the growing population. Reduction in damage by insect pests is one of the potential areas for increasing food production, and it is in this context that we should focus our attention on the likely effects of global warming and climate change on the activity and abundance of insect pests and their implications for crop protection and food security.

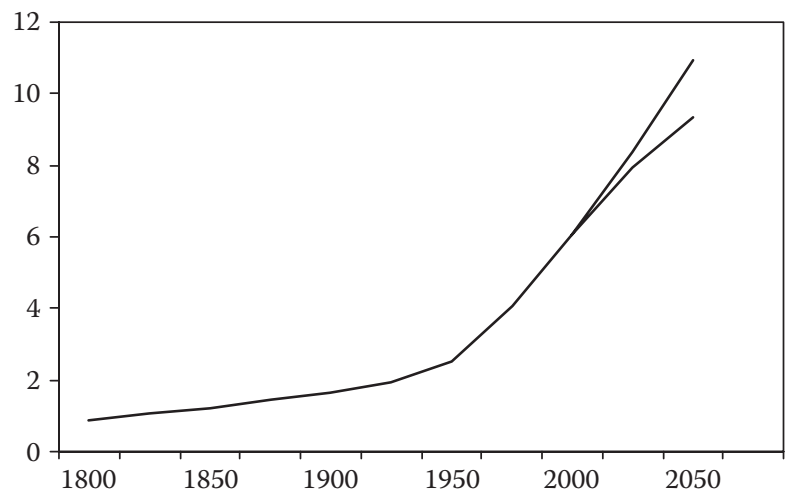

Figure 12.1 Expected population increase over the next 50 years. 


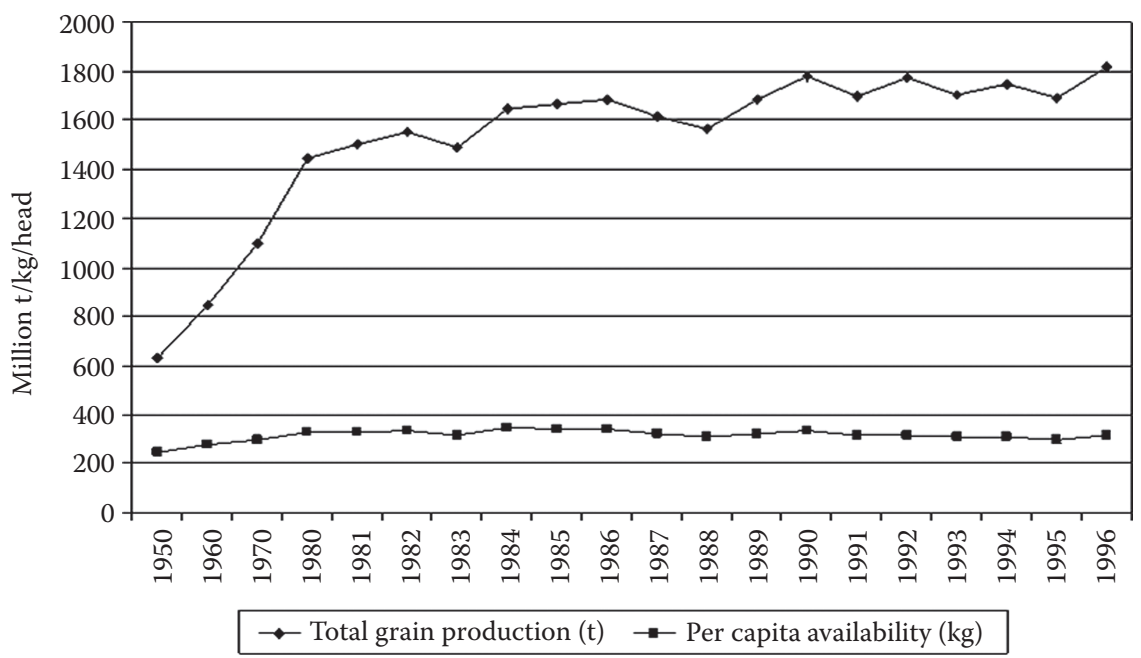

Figure 12.2 Food production and per capita availability of food over the past 50 years.

\section{INSECT RESPONSE TO CLIMATE CHANGE}

Insects are likely to be most affected by climate change because environmental factors have a strong influence on the development, reproduction, and survival of insect pests and their natural enemies (Bale et al., 2002). Insects have short generation times and high reproductive rates, and hence they are more likely to respond quickly to climate change than plants and vertebrates. Potential responses will include changes in phenological patterns, habitat selection and expansion, and/or contraction of geographic distribution. Species responses are expected to be idiosyncratic, depending on the flexibility of life history characteristics, and different growth rates and diapause requirements may influence species distribution and population increase (Bale et al., 2002). Fast-growing, nondiapausing species or those not dependent on low temperatures to induce diapause will respond to warming by expanding their distributions, whereas slow-growing species, which need low temperatures to induce diapause, will suffer range contractions.

Global warming will lead to faster development of immature stages, and adults will emerge much earlier than before. Observed responses include early adult emergence and an increase in the length of the flight period. Changes in butterfly phenology have been reported in Europe (Roy and Sparks, 2000; Stefanescu et al., 2003), and species have advanced their flight periods by $2-10$ days for every $1{ }^{\circ} \mathrm{C}$ increase in temperature. In Spain, butterflies appeared earlier by 1 and 7 weeks during the past 15 years, and by 8 days per decade in California (Forister and Shapiro, 2003). Several species of microlepidoptera have also shown temporal shifts in their phenology in Europe (Ellis et al., 1997). Early adult emergence and early arrival of migratory aphids have been observed in the United Kingdom (Zhou et al., 1995). A common phenological response has been observed in four unrelated species of insects (a butterfly, a bee, a fly, and a beetle) (Gordo and Sanz, 2005). In most cases, earlier appearance was correlated with an increase in spring temperatures. Global warming and changes in climate will influence

- Activity, diversity, and abundance of insect pests

- Geographical distribution of insect pests

- Overwintering; development and population dynamics

- Expression of host-plant resistance to insects

- Pest outbreaks and pest invasion

- Synchrony between plants and insect pollinators

- Effectiveness of crop protection technologies 
As a result of global warming, insects may find suitable alternative habitats at greater latitudes and higher altitudes. Genetic variation and multifactor inheritance of innate recognition of environmental signals may mean that many insect species will have to adapt readily to such disruption. Many species may also have their diapause strategies disrupted as the linkages between temperature, moisture regimes, and day lengths will be altered. Climate change will also result in increased problems with insect-transmitted diseases. These changes will have major implications for food security, particularly in developing countries where the need to increase and sustain food production is most urgent. Long-term monitoring of population levels and insect behavior, particularly in identifiably sensitive regions, may provide some of the first indications of a biological response to climate change. In addition, it is also desirable to keep ahead of undesirable pest adaptations, and it is important to consider global warming and climate change for planning research and development efforts for pest management and ensuring food security.

\section{INSECTS AS INDICATORS OF CLIMATE CHANGE}

Arthropods can be used as good bioindicators of human-driven changes in the environment, such as pollution, habitat loss, and fragmentation (McGeoch, 1998), and monitoring of terrestrial arthropods can provide early warnings of ecological effects attributable to climate change. Insects can also be used as examples of how biodiversity and community structure are affected by climate change. However, we still have a long way to go in understanding the detrimental and beneficial effects of human-induced climate change on biological systems. Arthropods can serve as good indicators of environmental change more easily than vertebrates and plants (Scherm et al., 2000; Gregory et al., 2009). For monitoring purposes, indicator assemblages should exhibit varying sensitivities to environmental changes and show diversity in life history and ecological interactions. Realistic information on arthropod diversity must be integrated into policy planning and management practices if ecosystems are to be managed for use by future generations. Ecosystem baselines that document arthropod species assemblages that are comparable in space and time are important for the interpretation and implementation of strategies designed to mitigate the effects of global warming and climate change.

\section{CLIMATE CHANGE AND ARTHROPOD DIVERSITY}

Large-scale changes in rainfall caused by global warming will also have a major bearing on the abundance and diversity of arthropods. Extreme climatic events, such as drought, are likely to decrease multitrophic diversity and change the composition of arthropod communities, which, in turn, may affect other associated taxa. Arthropods (insects, spiders, and mites) are the most abundant and diverse group of organisms (Kannan and James, 2009; Gregory et al., 2009) (Table 12.1). Insect pests are an important component of terrestrial and aquatic ecosystems and occupy a wide variety of functional niches and microhabitats (Kremen et al., 1993). Responses of arthropods to pollution depend on both temperature and precipitation; ecosystem-wide effects are likely to increase under predicted climate change (Zvereva and Kozlov, 2010). Consequences of temperature increases of $1^{\circ} \mathrm{C}$ to $2^{\circ} \mathrm{C}$ will be comparable in magnitude to the currently seen climate change in the Antarctic region, for example, after two seasons of experimental warming, the total abundance of Collembola decreased in the lichen community as a result of the population decline of the isotomid Cryptopygus antarcticus Willem. There was also a significant decline of mesostigmatid predatory mite, Gamasellus racovitzai (Trouessart), and a significant increase in the total number of Prostigmata (Bokhorst et al., 2008). The main effects of climate change and pollution on 
Table 12.1 Species Diversity among Different Groups of Organisms

\begin{tabular}{lc}
\hline Organisms & Number of Species \\
\hline Protoctists (algae, protozoa, etc.) & 80,000 \\
Bacteria & 4,000 \\
Fungi & 72,000 \\
Plants & 270,000 \\
Invertebrates (arthropods: insects, spiders, mites, etc.) & $1,272,000$ \\
Vertebrates & 52,000 \\
Total number of described species & $1,750,000$ \\
Possible unknown species & $14,000,000$ \\
\hline Source: UNEP-WCMC, Global Biodiversity: Earth's Living Resources in the 21st
\end{tabular}

Century, World Conservation Press, Cambridge, United Kingdom, 2000.

arthropod communities will be a decreased abundance of decomposers and natural enemies and increased herbivory, which may have negative consequences for the structure and services of entire ecosystems. For example, an increase in the amount of rainfall in the pampas region of Argentina has been shown to affect species with poor dispersal capabilities (Xannepuccia et al., 2009). At higher trophic levels, an indirect effect related to habitat loss and a reduction in prey availability has also been observed. In forest ecosystems, chronic stress significantly altered community composition, and the trees growing under high stress supported one-tenth the number of arthropods compared with trees growing under more favorable conditions (Talbot Trotter et al., 2008). Increased levels of tree stress are associated with an 8- to 10-fold decline in arthropod species richness and abundance. Arthropod richness and abundance on individual trees were positively correlated with a tree's radial growth during drought, suggesting that tree ring analysis could be used as a predictor of arthropod diversity (Stone et al., 2010).

\section{CLIMATE CHANGE AND SPECIES EXTINCTION}

Climate change will become a major factor for the extinction of arthropod species (Thomas et al., 2004; Butchart et al., 2005). Mountain species and those restricted to high latitudes are most likely to become extinct as a result of climate change. The species adapted to cold conditions will be forced to move uphill to higher latitudes as a result of global warming. Some of the species may eventually run out of habitable areas and inevitably become extinct. Species decline is difficult to detect and takes place across several hundreds of years. There has been a considerable change in British butterfly species richness between 1970 and 1999 (Menéndez et al., 2006). Four butterfly species have disappeared from lower latitudes during the past 25 years in the United Kingdom, with climate change being responsible for at least half of the population extinctions (Franco et al., 2006). In Spain, lower elevation limits of 16 mountain butterflies have increased in altitude by around $212 \mathrm{~m}$ as a result of global warming (Wilson et al., 2005). Speciation takes between 100 and 1,000,000 years, resulting in 10-10,000 new species per annum. Nearly $99.9 \%$ of all species that ever existed have become extinct. We are now living through the sixth extinction spasm, which is largely driven by human activities. The relative abundance of different insect species may change rapidly because of climate change, and the species unable to withstand the stresses may be lost in the near future (Thomas et al., 2004; Jump and Penuelas, 2005). The current extinction rates are 100-1000 times greater than what they were earlier, and nearly $45-275$ species are becoming extinct every day. It is difficult to attribute extinctions solely to climate change because of the potential of other drivers of extinction, such as habitat loss and invasive species. 


\section{EFFECT OF CLIMATE CHANGE ON SPECIES INTERACTIONS}

Climate-driven range expansion has created new interactions with potentially devastating consequences for crop production and food security. Changes in phenological patterns and distribution of individual species will result in altered species interactions within communities. The magnitude of response will differ between species, and there is considerable potential for the disruption of existing interactions among species (Visser et al., 2004). Interactions that involve two or more trophic groups, such as plant-herbivore, plant-pollinator, and insect-host-natural enemy interactions, are likely to undergo a major change (Harrington et al., 1999). Some plant species may be unable to cope with climate change, resulting in the extinction of species that are specific to particular host plants (Thomas et al., 2004). Distributional changes are also expected to bring about changes in species interactions because some species are likely to expand their distribution to different areas, for example, the pine processionary moth, Thaumetopoea pityocampa (Denis \& Schiff.), has moved to higher elevations during the last 20 years as a result of increasing temperature and has encountered a new host, Scots

AU: Please check if this should مמم "bud b al

AU: Please copfing the s pine (Pinus sylvestris [L.] var. nevadensis $\mathrm{H}$. Christ.). In warmer years, the defoliation by this insect has increased from 5\%-25\% above $1700 \mathrm{~m}$ (Hódar and Zamora, 2004). Many insect species have also advanced their phenology faster than their resources (budburst and flowering) (Visser and Both, 2005). An increase of $3^{\circ} \mathrm{C}$ in mean daily temperature would cause the carrot fly, Delia radicum (L.), to become active a month earlier than at present (Collier et al., 1991) and temperature increases of $5^{\circ} \mathrm{C}-10^{\circ} \mathrm{C}$ would result in the completion of four generations each year compared to two to three generations presently (Biron et al., 2000), necessitating the adoption of new pest control strategies. Global warming will lead to earlier infestation by insect pests, such as Helicoverpa zea (Boddie) in North America (EPA, 1989) and Helicoverpa armigera (Hub.) in north India (Sharma, 2010), resulting in increased crop losses. Rising temperatures are likely to result in the availability of new niches for insect pests. The emergence of some insect pests from diapause now occurs much earlier than their natural enemies, resulting in a mismatch between the interacting species.

References and further reading are available at the end of this chapter.

\section{IMPACT OF CLIMATE CHANGE ON GEOGRAPHIC DISTRIBUTION OF INSECT PESTS}

Climate change will have a major effect on geographic distribution of insect pests, and low temperatures are often more important than high temperatures in determining the distribution (Hill, 1987). A common approach in predicting developmental dynamics and migration of insects in relation to weather conditions involves the use of degree-day models (Bryant et al., 1998; Roltsch et al., 1999). However, temperature does not act in isolation to influence pest status, and therefore it is important to consider interactions with other variables, such as rainfall, humidity, radiation, and $\mathrm{CO}_{2}$ concentrations (Harrington et al., 2001). Increasing temperatures may impart greater ability to insect species limited by low temperatures at higher latitudes to overwinter, extending their geographical range (EPA, 1989; Hill and Dymock, 1989; Elphinstone and Toth, 2008). Sudden outbreaks of insect pests can wipe out certain crop species and also encourage invasions by exotic species (Kannan and James, 2009). Spatial shifts in the distribution of crops under changing climatic conditions will also influence the distribution of insect pests in a geographical region (Parry and Carter, 1989). However, whether or not an insect pest would move with a crop into a new habitat will depend on other environmental conditions, such as the presence of overwintering sites, soil type, and moisture.

Numerous cases of recent distributional shifts have been recorded for a variety of taxa around the world (Wilson et al., 2005). Changes in species distribution ranges have been documented in butterflies in North America and Europe, where species have shifted their ranges northward and to higher elevations as a result of global warming (Parmesan, 1996; Konvicka et al., 2003; Wilson et al., 2005). Many 


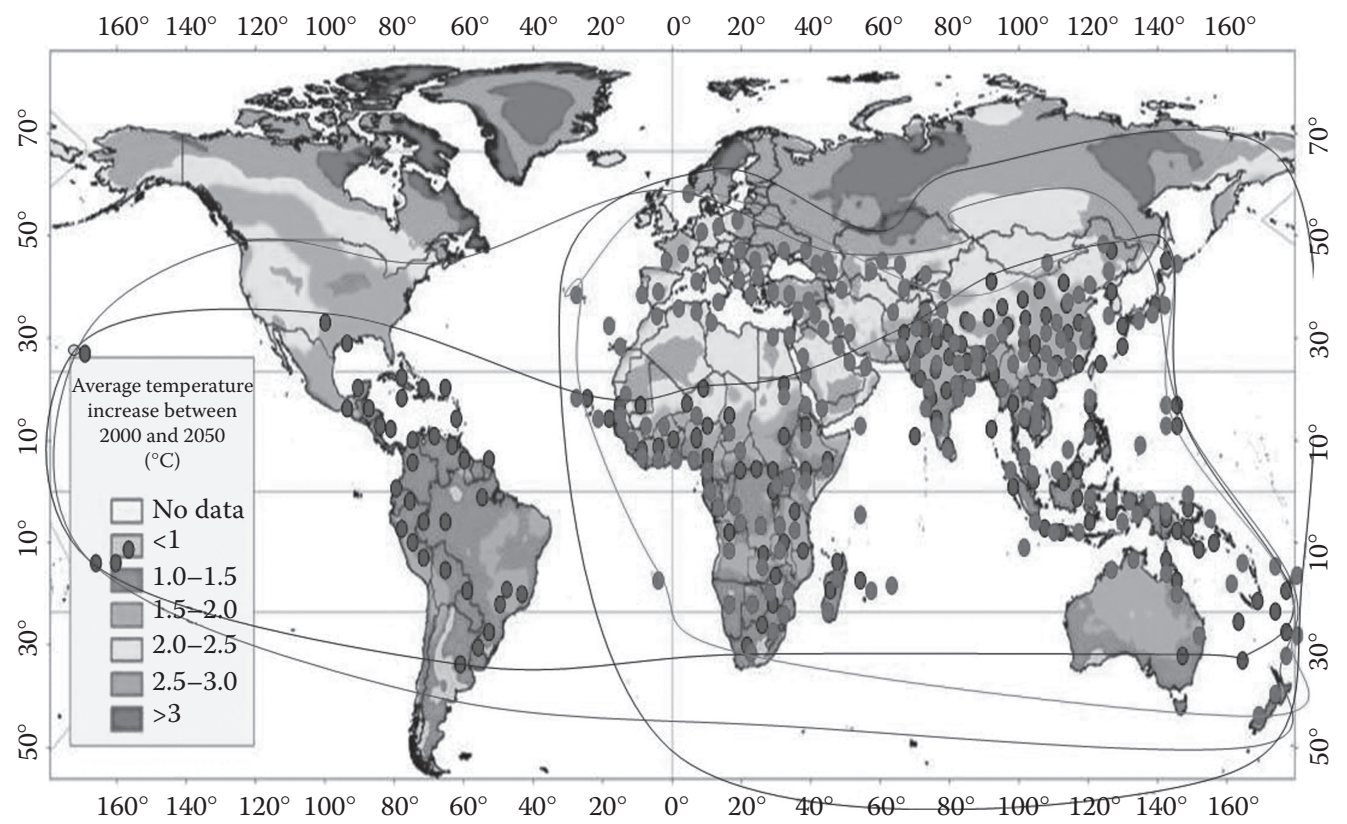

Figure 12.3 (See color insert.) Likely changes in geographical distribution of Helicoverpa armigera (red line: current, and black line likely distribution in future), and Maruca vitrata (blue line current and brown line future distribution).

beetles, butterflies, dragonflies, grasshoppers, and aquatic bugs have moved northward and to higher elevations in the United Kingdom (Hickling et al., 2006). Populations of corn earworm, H. zea, in North America might move to higher latitudes/altitudes, leading to greater damage to maize and other crops (EPA, 1989). The legume pod borers H. armigera and Maruca vitrata (Geyer) (Figure 12.3), presently confined to tropical climates in Asia, Africa, and Latin America, are most likely to move to northern Europe and North America over the next 50 years as a result of global warming and climate change (Sharma, 2010). Increases of $1^{\circ} \mathrm{C}$ and $3^{\circ} \mathrm{C}$ in temperature would cause northward shifts in the potential distribution of the European corn borer, Ostrinia nubilalis (Hub.), up to $1220 \mathrm{~km}$, with an additional generation in nearly all regions where it is currently known to occur (Porter et al., 1991). Although long-term distributional data are not available for lower latitudes and from tropical areas, movements of tropical species into temperate regions have also been reported (Paulson, 2001). Range expansions have been recorded more often than range contractions. However, this pattern can be attributed partially to failure to detect species declines (Thomas et al., 2006). When distributions are recorded at a broader scale, only one population needs to be established in a region to detect expansions. However, the extinction of all populations from a region is needed to detect species declines.

\section{EVOLUTIONARY CHANGES AND EMERGING PEST PROBLEMS}

Global warming may change the flowering times of plants, leading to ecological consequences, such as the introduction of new insect pests and the attainment of pest status by nenpest insects (Fitter and Fitter, 2002; Parmesan and Yohe, 2003; Willis et al., 2008). Climate change will alter selection pressures within populations because most populations are adapted to their local environments. Traits that confer fitness in an environment might not be as successful under new climatic conditions, and therefore it is imperative that evolutionary responses take place. The potential of evolutionary changes is quite high among insects as they grow fast, have short generation times, and have high reproductive rates. Insects will adjust rapidly to new environmental conditions because 
of faster generation turnover than other animals. Therefore, it is not surprising that most empirical evidence of evolutionary changes has come from insect species (Parmesan, 2006). Adaptation to climate change has also been observed in species with high frequencies of preexisting hightemperature-tolerant genotypes. Chromosomal inversion polymorphism in Drosophila species changes with latitude and is related to climatic factors. Under warm climatic conditions, the frequency of high-temperature-adapted genotypes increases considerably within existing populations (Rodríguez-Trelles and Rodríguez, 1998; Levitan, 2003; Umina et al., 2005; Balanyá et al., 2006). However, true evolutionary responses have also been reported in the timing of life cycles. Mosquito larvae of pitcher-plant mosquito, Wyeomyia smithii (Coq.), enter overwintering state at an earlier date in the northern latitudes than in the south, and overwintering is genetically heritable within populations. The delay in the life cycle has been attributed to evolutionary response to increased length of the growing season (Bradshaw and Holzapfel, 2001).

\section{IMPACT OF CLIMATE CHANGE ON THE BIOLOGY AND POPULATION DYNAMICS OF INSECT PESTS}

Higher temperatures below the species' upper threshold limit will result in rapid development and increases in pest populations as the time to reproductive maturity will be reduced considerably. In addition to the direct effects of temperature changes on development rates, improvement in food quality because of abiotic stresses may result in dramatic increases in the growth rates of some insect species (White, 1984), whereas the growth of certain insect pests may be affected adversely (Maffei et al., 2007). Overwintering of insect pests will increase as a result of climate change, producing larger spring populations as a base for a buildup in numbers in the following season. These may be vulnerable to parasitoids and predators if the latter also overwinter more readily. The diamond back moth, Plutella xylostella L., was able to overwinter in Alberta, Canada, in 1994 (Dosdall, 1994), and if overwintering becomes common the status of this insect as a pest in North America will increase dramatically. Some insect species, such as cicadas and Arctic moths, take several years to complete one life cycle, and these insects will react to temperature dur-

AU: Please specify if this is same as "degree days." ing the course of their life history. With a $2^{\circ} \mathrm{C}$ increase in temperature, these insects might have one to five additional life cycles per season (Yamamura and Kiritani, 1998). Temperature has a strong influence on the viability and incubation period of $H$. armigera eggs, which can be predicted on the basis of "day degrees" required for egg hatching (Dhillon and Sharma, 2007).

Insect populations vary across seasons and locations. Both the onset of insect infestation and population buildup are influenced by the weather conditions during the crop growing season and/ or during the preceding period. Because no two seasons have similar weather conditions, the insect population dynamics also varies across seasons and locations, for example, there is a large variation in the peak population of Oriental armyworm, Mythimna separata (Walk.), at ICRISAT-Patancheru, Andhra Pradesh, India, across seasons (Figure 12.4). Maximum moth catches in light traps were recorded during the 31st standard week in 1980 and the 40th standard week during 1976. Adults of M. separata are generally caught in light traps 15-20 days after the initiation of the monsoon rains in the first week of June, and they reach a peak in September, nearly 1 month after the peak in larval density (Sharma et al., 2002b). Rain and maximum and minimum relative humidity are positively associated with moth catches in the light traps, whereas maximum temperature, open pan evaporation, solar radiation, sunshine hours, and wind velocity have a negative correlation with moth abundance. The population density (PY) of sorghum head bug, Calocoris angustatus Leth., is influenced by rainfall $(R)$, maximum $\left(T_{\max }\right)$ and minimum $\left(T_{\min }\right)$ temperatures, and maximum $\left(\mathrm{RH}_{\max }\right)$ and minimum $\left(\mathrm{RH}_{\text {min }}\right)$ relative humidity prevailing during the previous 2 weeks (SW2): (PY $=220+$ $0.6 R+44.3 T_{\max }-113.1 T_{\min }+15.6 \mathrm{RH}_{\max }-5.7 \mathrm{RH}_{\min }$ ) (Sharma and Lopez, 1994). The population and incidence of cotton bollworm/legume pod borer, H. armigera, in southern India is influenced 


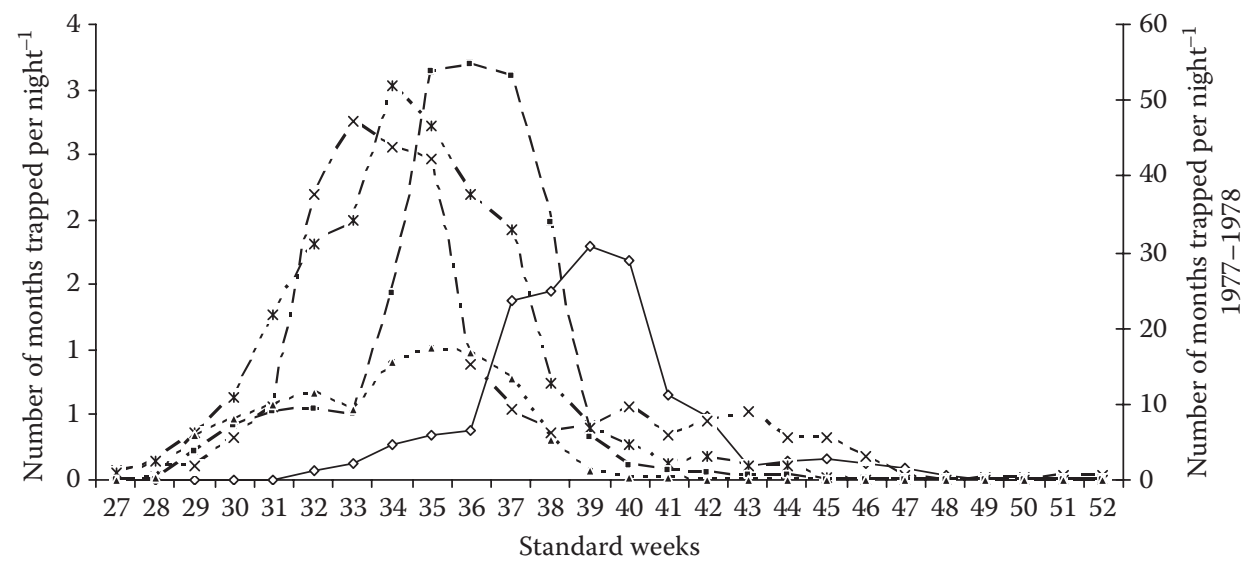

$\multimap-1976 \quad--x \cdots 1979 \quad--*--1980 \quad----1977 \quad \cdots \cdots 1978$

Figure 12.4 Population dynamics of the Oriental armyworm, Mythimna separata, from 1976 to 1980.

by the amount of rainfall during the rainy and the postrainy seasons (high incidence $=+A+B$, moderate incidence $=-A+B$, and low incidence $=-A-B$, where $A=$ June-September rainfall and $B=$ October-November rainfall) (Das et al., 2001). The onset of insect infestation and population dynamics will become more variable under global warming and climate change, thus making it more difficult to plan and undertake measures to control the damage by insect pests.

An increase of $2^{\circ} \mathrm{C}$ in temperature will reduce the generation turnover of the bird cherry aphid, Rhopalosiphum padi (L.), by varying levels, depending on the changes in mean temperature (Morgan, 1996). There may also be increased dispersal of airborne insect species in response to atmospheric disturbances. Many insects such as H. armigera, Mythimna separata (Wallk.), and Spodoptera litura (F.), which are migratory, may be well able to exploit new opportunities by moving rapidly into new areas as a result of climate change (Sharma et al., 2002b; Sharma, 2005, 2010). Pest outbreaks are more likely to occur with stressed plants as a result of weakening of the plants' defensive system, thus increasing their level of susceptibility to insect pests (Rhoades, 1985). However, many plant species in tropical regions have the capability to withstand the phenological changes that are a result of climate change (Corlett and LaFrankie, 1998).

\section{EFFECT OF CLIMATE CHANGE ON THE ACTIVITY AND ABUNDANCE OF INSECT POLLINATORS}

Anthropogenically induced temperature increases have the potential to affect the phenology of both plants and pollinators. Many plants have reacted to increasing temperatures by earlier flowering (Fitter and Fitter, 2002; Menzel et al., 2006; Miller-Rushing et al., 2007). Insect-pollinated plants generally react more strongly to increased warming than wind-pollinated plants and species flowering early in the season appear to be the most sensitive (Fitter and Fitter, 2002; Miller-Rushing et al., 2007). The onset of flowering is correlated with mean temperature in the month of flowering or in the months prior to flowering (Sparks et al., 2000; Menzel et al., 2006). Photoperiod, precipitation, soil humidity, and snow melting also have a bearing on flowering and pollination (Inouye et al., 2003). If climate change disrupts the relationships among the environmental cues that plants use to initiate flowering, past combinations of cues might reappear at novel times in the season (Price and Waser, 1998), resulting in "bizarre" flowering times. Such future responses not only depend on a 
plant species' direct response to temperature or other cues but be modified ecologically or through evolutionary interactions with pollinators. In general, global warming will result in

- Altered phenology of plants

- Altered composition of pollinators

- Extinction and/or emergence of new pollinators

- Asynchrony in pollinator activity and plant phenology

- Landscape changes caused by changes in plant communities and pollinators

AU: Please check if all occurrences

Global warming will affect both the phenology of plants and the abundance of insect pollinators. There is limited information on how the elevated temperatures affect plant-pollinator mutualism. The onset of flowering in plants and the first appearance of pollinators advance linearly in response to increased temperatures (Hegland et al., 2009). Phenological responses to climate may occur at the same time in the plants and the pollinators, although there may be considerable variation in responses across species. Despite the overall similarities in responses, a few studies have indicated that climate warming may generate temporal mismatches between the pollinators and the plants. Studies on multispecies plant-pollinator assemblages have indicated that the overall structure of pollination networks is quite robust against the disturbances caused by climate change.

Food availability is one of the important factors governing the activity and population density of pollinators (Hegland and Boeke, 2006; Steffan-Dewenter and Schiele, 2008). Different cues or combinations of cues may have a disproportionate influence on phenological events across species, ecosystems, and geographical regions. For example, bumblebee queen emergence in the Rocky Mountains is tied to snowmelt, as is the case for the plants they pollinate (Inouye, 2008). Tropical insects are most likely to experience the deleterious effects of global warming because of their narrow thermal tolerance, despite a lower temperature increase in tropical regions than in temperate regions (Deutsch et al., 2008). Identification of such fitness curves of thermal tolerance for plants and their pollinators will enable simulations of potential future mismatches among the plants and the insect pollinators. The population dynamics of pollinators is also controlled by resource availability, for example, floral resources and nesting sites in a geographical region. Because many plants and pollinators are generalists (Waser et al., 1996), an understanding of the outcome of a single interaction between two mutualistic species may be quite unrealistic. Manipulation of resource availability and subsequent assessment of population dynamics of pollinators will be important for estimating potential consequences of climate change (Steffan-Dewenter and Schiele, 2008).

\section{EFFECT OF CLIMATE CHANGE ON PEST MANAGEMENT AND FOOD SECURITY}

Host plant resistance, biopesticides, natural enemies, and synthetic chemicals are some of the potential options for pest management. However, the relative efficacy of many of these pest control measures is likely to undergo change as a result of global warming. Changes in precipitation are of greater importance for agriculture than temperature changes, especially in regions where the lack of rainfall may be a limiting factor for crop production (Parry, 1990). Global mean annual precipitation may increase as a result of the intensification of the hydrological cycle (Rowntree, 1990), which will cause disruption of agriculture as the cropping systems and the composition of fauna and flora undergo a gradual change (Porter et al., 1991; Sutherst, 1991). High mobility and rapid population growth will increase the extent of losses caused by insect pests. As a result of global warming, insect pests confined to tropical and subtropical regions may move to temperate regions along with a shift in the areas of production of their host plants. Global warming will

- Change the expression of host plant resistance to insects

- Affect the efficacy of insect-resistant transgenic crops 
- Affect the activity and abundance of natural enemies

- Reduce the effectiveness of bio-pesticides and synthetic pesticides for pest management

\section{EXPRESSION OF HOST PLANT RESISTANCE TO INSECT PESTS}

Host plant resistance to insects is one of the most environment-friendly components of pest management. However, climate change may alter the interactions between insect pests and their host plants (Bale et al., 2002; Sharma et al., 2005, 2010). There will be increased impact on insect pests that benefit from weakened host defenses as a result of the stress caused by the lack of adaptation to suboptimal climatic conditions. The chemical composition of some plant species changes in direct response to biotic and abiotic stresses, which renders the host plant less suitable for the growth and survival of insect pests (Sharma, 2002). Problems with new insect pests will occur if climatic changes favor the introduction of insect-susceptible cultivars or crops into new areas as one of the adaptive methods to mitigate the effects of climate change (Parry and Carter, 1989).

Climate change will affect the availability of water and, thus, indirectly affect plant growth and insect-host plant interactions. Populations of Aphis fabae Scop. have lower rates of reproduction on water-stressed plants (McMutry, 1962). High levels of water stress also reduce the damage by the sorghum shoot fly, Atherigona soccata (Rond.) (Soman et al., 1994). However, water-stressed plants of sorghum suffer greater damage by the spotted stem borer, C. partellus, and the sugarcane aphid, Melanaphis sacchari (Zehnt.), than the plants grown under irrigated conditions. Thus, moisture stress can alter plant reaction to insect damage, leading to either an increase or a decrease in insect damage. Atmospheric humidity also interferes with insect-plant interactions (Sharma et al., 1999). High humidity increases the ease of detection of odors and, thus, may influence host finding by insect pests. Unusually severe drought increases the damage by insect species, such as spotted stem borer, C. partellus (Swin.), in sorghum (Sharma et al., 2005). Sorghum genotypes with moderate levels of resistance to $C$. partellus exhibit a susceptible reaction under drought stress (Figure 12.5). Sorghum varieties exhibiting resistance to sorghum midge, Stenodiplosis sorghicola (Coq.), in India become susceptible to this pest under high humidity and moderate temperatures near the equator in Kenya (Sharma et al., 1999). Minimum temperature $\left(<18^{\circ} \mathrm{C}\right)$ and maximum relative humidity $(<60 \%)$ had a negative effect on midge damage in the midge-resistant

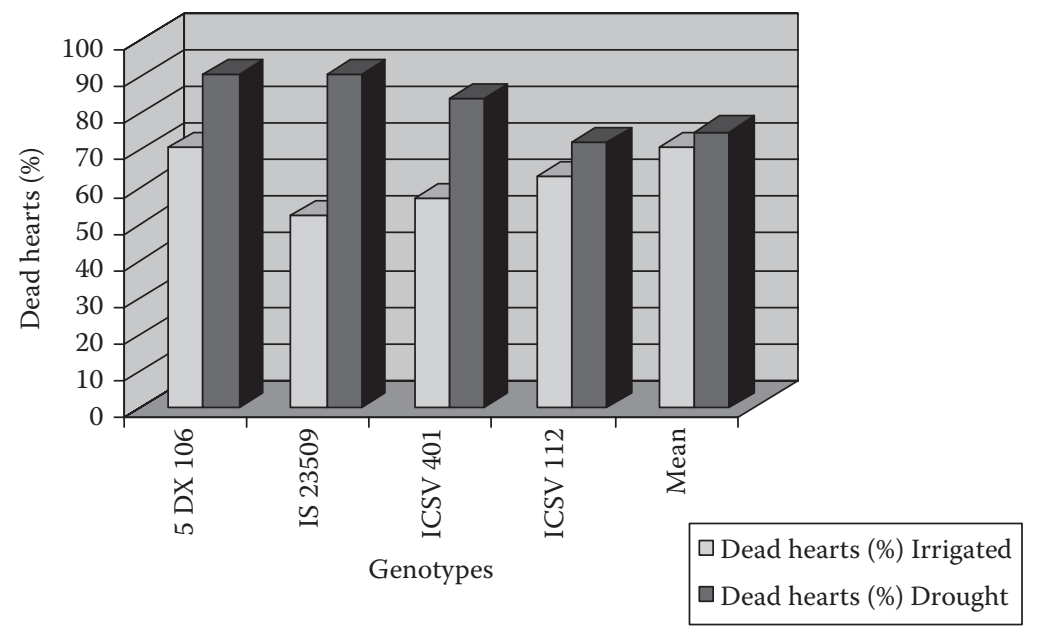

Figure 12.5 (See color insert.) Effect of drought on expression of resistance to the stem borer, Chilo partellus, in sorghum. 


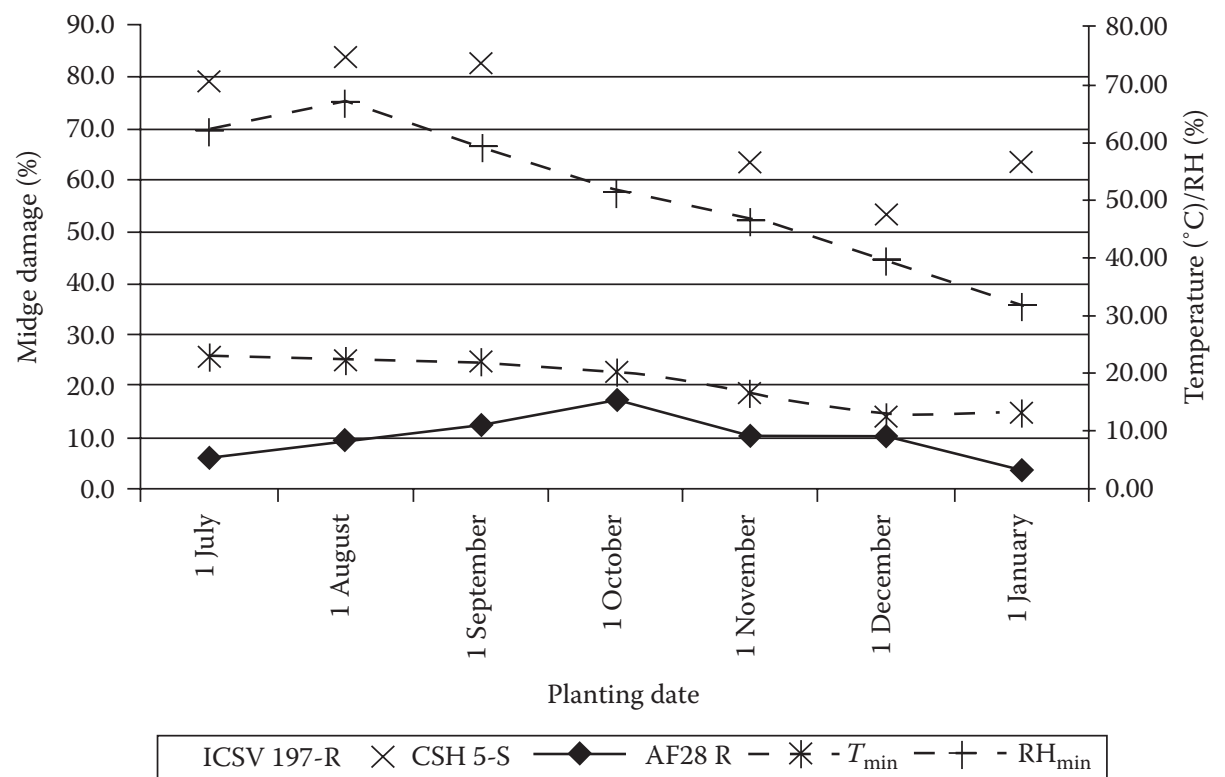

Figure 12.6 Influence of climatic conditions on midge, Stenodiplosis sorghicola, damage in sorghum.

cultivars ICSV 197 and AF 28 but not in the susceptible cultivar CSH 5 (Figure 12.6). The increase in head bug, angustatus Lethiery, population and grain damage across panicle sizes or infestation levels were greater during the rainy season compared with the dry season (Sharma and Lopez, 1994).

Insect-host plant interactions will also undergo a change in response to the effects of $\mathrm{CO}_{2}$ on nutritional quality and secondary metabolites of the host plants. Increased levels of $\mathrm{CO}_{2}$ will enhance plant growth, but they may also increase the damage caused by some phytophagous insects (Gregory et al., 2009). In the $\mathrm{CO}_{2}$-enriched atmosphere, many species of herbivorous insects will confront less nutritious host plants that could induce both lengthened larval developmental times and greater mortality (Coviella and Trumble, 1999). The effects of increased atmospheric $\mathrm{CO}_{2}$ on herbivory will not only be species specific but also be specific to each insect-plant system. Although increased $\mathrm{CO}_{2}$ levels tend to enhance plant growth rates, the larger effects of drought stress will probably result in slower plant growth (Coley and Markham, 1998). In atmospheres experimentally enriched with $\mathrm{CO}_{2}$, the nutritional quality of leaves declined substantially because of dilution of nitrogen by 10\%-30\% (Coley and Markham, 1998). Increased $\mathrm{CO}_{2}$ may also cause a slight decrease in nitrogen-based defenses (e.g., alkaloids) and a slight increase in carbon-based defenses (e.g., tannins). Acidification of water bodies by carbonic acid (because of high $\mathrm{CO}_{2}$ ) will also affect floral and faunal diversity (Gore, 2006). The lower foliar nitrogen content caused by $\mathrm{CO}_{2}$ causes an increase in food consumption by herbivores up to $40 \%$. Endophytes, which play an important role in conferring tolerance to both abiotic and biotic stresses in plants, may also undergo a change in response to the disturbance in soil caused by climate change (Newton et al., 2009). For forest insects, the performance of insect herbivores depends on the type of plant tissue available for consumption (Lindroth et al., 1993). The quality of foliage is better at the time of budburst, and therefore egg hatching long after budburst will be disadvantageous to the herbivores (Dewar and Watt, 1992). For a generalist herbivore, such as the gypsy moth, Lymantria dispar L., the loss of a single host can be catastrophic. This moth develops on red and black oaks, Quercus 
rubra and Quercus velutina; and eggs hatched before budburst will lead to starvation, whereas eggs hatched too late after budburst (resulting in reduced foliage quality) will lead to reduced fecundity (Ward and Masters, 2007).

\section{EXPRESSION OF RESISTANCE TO INSECTS IN TRANSGENIC CROPS}

Environmental factors, such as soil moisture, soil fertility, and temperature, have a strong influence on the expression of Bacillus thuringiensis (Bt) toxin proteins deployed in transgenic plants (Sachs et al., 1998). Possible causes for the failure of insect control in transgenic crops may be inadequate production of the toxin protein, effect of the environment on transgene expression, $B t$-resistant insect populations, and development of resistance because of inadequate management (Sharma and Ortiz, 2000; Sharma et al., 2004). Cotton bollworm, Heliothis virescens (F.), destroyed Bt-transgenic cottons because of high temperatures in Texas (Kaiser, 1996). Similarly, $H$. armigera and $H$. punctigera (Wallen.) destroyed $B t$-transgenic cotton in the second half of the growing season in Australia because of the reduced production of $B t$ toxins (Hilder and Boulter, 1999). The damage inflicted by bollworms on cotton, regardless of the presence or absence of insecticidal genes, is predicted to be more serious under elevated $\mathrm{CO}_{2}$ (Chen et al., 2005). Genetically modified cottons with $B t$-toxin genes have lower nitrogen, and higher carbon-nitrogen ratio, carbon defensive compounds, condensed tannin, and gossypol under elevated $\mathrm{CO}_{2}$, which results in a significant decrease in the $B t$ toxin expression and has a considerable influence on the effectiveness of transgenic crops for pest management (Coviella et al., 2002; Chen et al., 2005). The levels of $B t$ toxin CrylAc in transgenic plants decrease with plant age (Figure 12.7), resulting in greater susceptibility of the crop to insect pests during the later stages of crop growth (Sachs et al., 1998; Greenplate et al., 2000; Adamczyk et al., 2001; Kranthi et al., 2005). A decrease in relative humidity from $90 \%$ to $70 \%$, and increases in minimum and maximum temperatures from $9^{\circ} \mathrm{C}$ to $18^{\circ} \mathrm{C}$ and $25^{\circ} \mathrm{C}$ to $35^{\circ} \mathrm{C}$, respectively, increases the efficacy of transgenic cotton against the larvae of the bollworm, H. armigera (Figure 12.8). However, there is a significant decrease in biological activity once the minimum and maximum temperatures are $>22^{\circ} \mathrm{C}$ and $>38^{\circ} \mathrm{C}$, respectively. It is therefore important to understand the effects of climate change on the efficacy of transgenic plants for pest management.

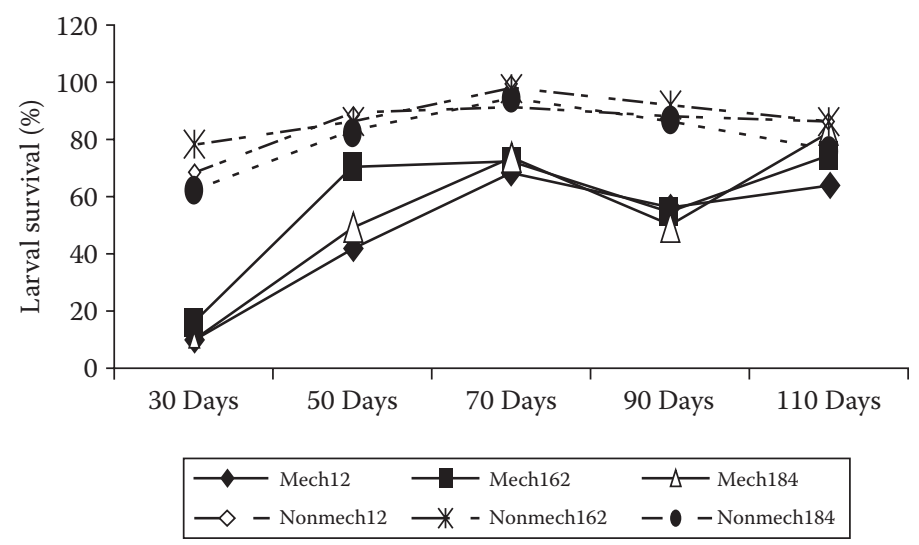

Figure 12.7 Expression of resistance to the bollworm, Helicoverpa armigera, in Bacillus thuringiensis transgenic cotton over the crop growing season. 


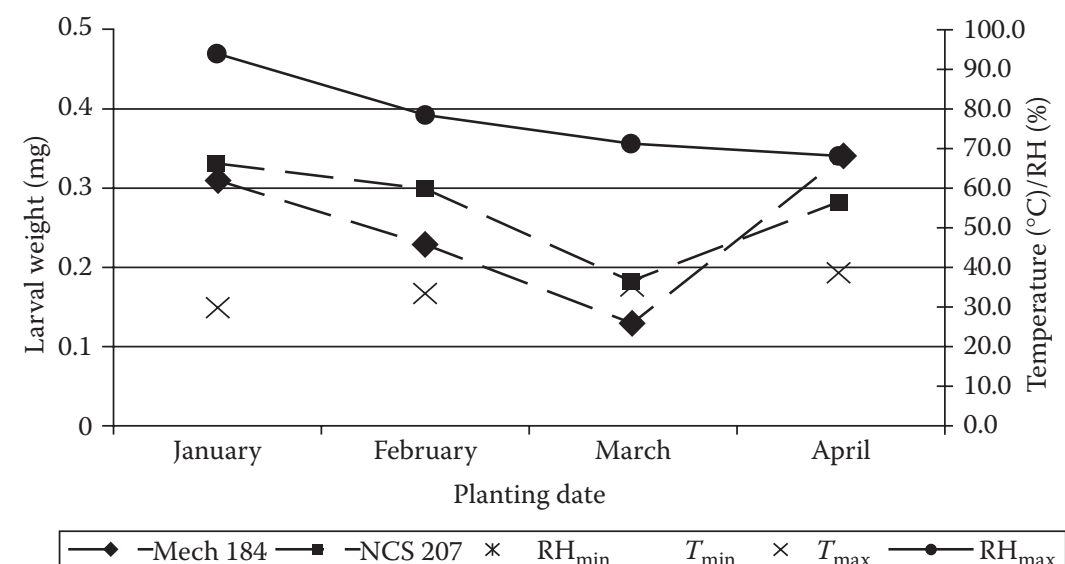

Figure 12.8 Effect of climatic factors on expression of resistance (larval weight) in Bacillus thuringiensis transgenic cotton to the bollworm, Helicoverpa armigera.

\section{MARKER-ASSISTED SELECTION AND CLIMATE CHANGE}

Marker-assisted selection (MAS) can be used to accelerate the pace of transferring insectresistant genes into improved cultivars to overcome the effects of climate change. Molecular mark-

AU: Please specify what " $\mathrm{F}_{2}$ " refers to. $\Omega$ ers, such as random-amplified polymorphic DNAs, restriction fragment-length polymorphisms, microsatellites and polymerase chain reaction (PCR)-based DNA markers, such as sequence characterized amplified regions, simple sequence repeats, sequence tagged sites, amplified fragmentlength polymorphic DNAs, based on $\mathrm{F}_{2}$ and backcross populations, near isogenic lines, doubled haploids and recombinant inbred lines, can be used for MAS for insect resistance (Yencho et al., 2000; Sharma et al., 2002a). Molecular markers can help in improving the efficiency of plant breeding by carrying out selections based on markers linked to a trait (Smith, 2005). Molecular markers are environment neutral and are detectable at all stages of plant growth. The expression of biochemical and morphological markers is influenced by the environment, and this makes them less reliable than the molecular markers. A number of methods have been used for mapping quantitative trait loci associated with insect resistance. Molecular markers linked with insect resistance have been identified in several crops, and the success of MAS depends on availability of techniques to screen large populations and high reproducibility of the phenotypic data (Sharma, 2009). Potential benefits of this approach have been discussed widely, but at the moment there are very few examples of successful application of this approach to develop cultivars with broad-based resistance to insects. Once the markers linked closely to the resistance genes are identified, MAS can be practiced in early generations at early stages of plant development and can speed up the selection process (Yencho et al., 2000). Marker-assisted selection can also be used for gene pyramiding from diverse sources to overcome the effects of climate change.

\section{ACTIVITY AND ABUNDANCE OF NATURAL ENEMIES}

Quantifying the effect of climate change on the effectiveness of natural enemies will be a major concern in future pest management programs. Tritrophic interactions between plants, herbivores, and parasitoids are the result of a long coevolutionary process, which is specific to a particular environment. Relationships between insect pests and their natural enemies will change as a result of global warming, resulting in both increases and decreases in the status of individual pest species. 
The higher trophic levels are more likely to be affected by climate change because they depend on the capacity of the lower trophic levels for development and survival. Biodiversity plays an important role in the relative abundance of insect pests and their natural enemies, and there is a need to increase functional diversity in agroecosystems vulnerable to climate change to improve system resilience and decrease the extent of losses caused by insect pests (Newton et al., 2009). Changes in cropping patterns as a result of climate change will drastically affect the balance between insect pests and their natural enemies. Because climate change will lead to a shift in cultivation of crops in nontraditional areas, this may influence the prevalence and importance of specific insect pests and their natural enemies (Maiorano et al., 2008). System diversity can be exploited to enhance the resilience of agroecosystems, improve resource utilization, and stabilize yields to cope with the effects of global warming and climate change on food security (Alteiri 1994; Sharma and Waliyar, 2003; Newton et al., 2009).

Changes in temperature will alter the pattern and timing of diurnal activity of different groups of insects (Young, 1982), and changes in interspecific interactions could also alter the effectiveness of natural enemies for pest management (Hill and Dymock, 1989). The majority of insects are innocuous to agroecosystems, and there is considerable evidence to suggest that this is because of population control through interspecific interactions among the insect pests and their natural enemies-pathogens, parasites, and predators (Price, 1987). Oriental armyworm, M. separata, populations increase during extended periods of drought, which is detrimental to its natural enemies, followed by heavy rainfall (which is favorable to the armyworm) (Sharma et al., 2002b). Increasing climatic variability has resulted in a reduced level of parasitism of caterpillars, which in turn may increase the frequency and intensity of herbivore outbreaks (Stireman et al., 2005).

Aphid abundance increases with an increase in $\mathrm{CO}_{2}$ and temperature; however, parasitism rates remain unchanged under elevated $\mathrm{CO}_{2}$. Temperature increases up to $25^{\circ} \mathrm{C}$ will enhance the control of aphids by coccinellids (Freier and Triltsch, 1996). Parasitoids depend on their insect hosts to develop, and exposure of either the insects or the parasitoids to stressful temperatures will induce lethal and sublethal effects on the parasitoids. Temperature not only affects the rate of insect development but also has a profound effect on fecundity and sex ratio of the parasitoids (Dhillon and Sharma, 2008, 2009). It also decreases longevity, mobility, ability to orient toward odors, and learning capacities. The endosymbiont bacteria associated with either parasitoids or their insect hosts are also suppressed by short exposures to high temperatures. Because climate change affects the insect hosts and their parasitoids differently, it may lead to a change in the distribution range of different species, resulting in rearrangements of insect communities, including the parasitoids (Hance et al., 2007). Climate change will also disturb the predator-prey and parasitoid-host interactions and even alter the balance between insect pests, natural enemies, and host plants because of alterations in their synchrony. A rise in temperature will generally favor insect development and survival in winter season (Evans et al., 2002). Therefore, the interactions between insect pests and their natural enemies need to be studied carefully to devise appropriate methods for using natural enemies in pest management programs in the future.

\section{EFFECTIVENESS OF BIOPESTICIDES}

Growing awareness about the hazardous effects of synthetic pesticides has led to increasing interest in the use of biopesticides in pest management. Natural plant products, entomopathogenic viruses, fungi, bacteria, and nematodes are highly sensitive to climate change. An increase in temperatures and ultraviolet (UV) radiation and a decrease in relative humidity may render many of these control tactics less effective, and such an effect will be more pronounced on natural plant products and biopesticides (Isman, 1997). However, changes in temperature, relative humidity, $\mathrm{CO}_{2}$, and UV radiation have shown differential effects on biopesticides (Lathika and Jacob, 1974; 
Verhaar et al., 1998; Coviella and Trumble, 2000; Godoy et al., 2007; Campos-Herrera et al., 2010). Temperature and humidity are the key factors for the activity of entomopathogenic fungi and nematodes, and very low and very high temperatures result in a significant loss of biological activity (Kung et al., 1991; Chen et al., 2003; Ganguly and Gavas, 2004). Several studies have shown that the virulence of entomopathogenic bacteria on insect pests increases at high temperatures (van Frankenhuyzen, 1994). In case of entomopathogenic fungi and viruses, high relative humidity is associated with high mortality in insect hosts, but the effects on insect hosts infected with bacteria are quite variable (Walstad et al., 1970; Thompson et al., 2006). UV light is known to affect the biological activity of biopesticides adversely (Krieg et al., 1980). Insect viruses are inactivated by extreme temperatures, sunlight, and UV radiation (Krieg et al., 1980; Thompson et al., 2006).

An increase in $\mathrm{CO}_{2}$ concentration significantly reduces spore germination and growth rates but increases insect mortality because of disruptions in $\mathrm{C} / \mathrm{N}$ balance and increases in food consumption. Similar effects have also been observed on biopesticides based on viruses and bacteria (Coviella and Trumble, 2000). Fungal development is influenced by soil pH (Thompson et al., 2006). The quantity of insecticidal active constituents of plants is also affected by changes in climatic conditions (Ermel et al., 1986; Rengasamy and Parmar, 1995; Kaushik et al., 2007). Environmental influences on insect-pathogen interactions operate through the biology of the pathogen, the immune response of the insect, and/or the rate of pathogen entry into the insect. Therefore, the effectiveness of pesticides will vary with environmental conditions. In situations where biopesticides are used as a component of pest management, environmental conditions should be considered carefully while selecting a product for use in pest management.

\section{EFFICACY OF SYNTHETIC INSECTICIDES}

There will be an increase in variability in insect damage as a result of climate change. Higher temperatures will make dry seasons drier and, conversely, may increase the amount and intensity of rainfall, making wet seasons wetter than at present. Rapid dissipation of insecticide residues because of increases in temperature and precipitation will require more frequent application of insecticides. A hot and humid climate will increase crop protection costs through more frequent use of pesticides for crop protection (Chen and McCarl, 2001). Changes in climatic factors, such as temperature, relative humidity, $\mathrm{CO}_{2}, \mathrm{pH}$, rainfall, and soil properties, have shown varying effects on the efficacy of synthetic

AU: Should this be Achik et al., 1989 , to match the reference list? If not, please provide the reference details for this 1 non. pesticides. Temperature has shown a positive effect on organochlorines, organophosphates, and carbamates (although there are a few exceptions) but has shown a negative effect on synthetic pyrethroids (Lydy et al., 1999; Li et al., 2006; Uddin and Ara, 2006; Wang and Shen, 2007). Higher temperatures and lower humidity values reduce the fumigation period of phosphine against Liposcelis bostrychophila (Badinnel) (Nayak and Collins, 2008). Soil texture, moisture, organic matter content, and organic acids influence toxicity and, in turn, affect the efficacy of insecticides for pest management (Achik et al., 1999). Rainfall reduces insecticide toxicity; however, the effects vary with the intensity and amount of rainfall, formulation, and the adjuvants used. Carbon dioxide, $\mathrm{pH}$, and sunlight have shown variable influences on insecticide toxicity (Warwick, 1985; Taylor and Matthews, 1986; Nayak and Collins, 2008). Therefore, there is a need to take a critical look at the effectiveness of various insecticides under global warming and climate change for sustainable crop production and food security.

\section{CONCLUSIONS}

Current estimates of climate change indicate an increase in global mean annual temperature and $\mathrm{CO}_{2}$ concentration and a decrease in annual precipitation, which might result in severe adverse effects on agroecosystems, resulting in changes in crop diversity and the availability of food. Global 
warming and climate change will trigger major changes in arthropod diversity, geographical distribution of insect pests, insect population dynamics, herbivore-plant interactions, activity and abundance of natural enemies, and efficacy of crop protection technologies for pest management. Distribution of insect pests and their natural enemies will also be influenced by changes in the cropping patterns triggered by climate change. Several insect species currently confined to tropical regions may move to temperate regions, resulting in greater damage to cereals, grain legumes, vegetables, fruit crops, and forest trees. Global warming will also reduce the effectiveness of host plant resistance, transgenic plants, natural enemies, biopesticides, and synthetic chemicals for pest management. As a result, economic relationships between the costs and benefits of pest control measures are expected to change. Therefore, there is a need to generate information on the likely effects of climate change on insect pests to develop robust technologies that will be effective and economical in the future under global warming and climate change.

\section{SUMMARY}

Global warming and climate change will trigger major changes in diversity and abundance of arthropods, geographical distribution of insect pests, insect population dynamics, insect biotypes, herbivore-plant interactions, activity and abundance of natural enemies, species extinction, and efficacy of crop protection technologies. Changes in geographical range and insect abundance will increase the extent of crop losses and, thus, will have a major bearing on crop production and food security. Distribution of insect pests will also be influenced by the changes in cropping patterns triggered by climate change. Major insect pests, such as cereal stem borers (Chilo, Sesamia, and Scirpophaga), pod borers (Helicoverpa, Maruca, and Spodoptera), aphids, and whiteflies, may move to temperate regions, leading to greater damage in cereals, grain legumes, vegetables, and fruit crops. Host plant resistance, biopesticides, natural enemies, and synthetic chemicals are some of the potential options for integrated pest management. However, the relative efficacy of many of these pest control measures is likely to change as a result of global warming. Climate change will also result in increased problems with insect-transmitted diseases. These changes will have major implications for crop protection and food security, particularly in developing countries where the need to increase and sustain food production is most urgent. Long-term monitoring of population levels and insect behavior, particularly in identifiably sensitive regions, may provide some of the first indications of a biological response to climate change.

\section{REFERENCES}

\section{AU: Please} provide text citations for the references Achik et al. (1989), Heong, and Domingo (1992), Sharma et al. (2003), Thomas

Achik, J., M. Schiavon, and G. Houpert. 1989. Persistence of biological activity of four insecticides in two soil types under field and laboratory conditions. J. Econ. Entomol. 82:1572-1575.

Adamczyk, Jr., J.J., L.C. Adams, and D.D. Hardee. 2001. Field efficacy and seasonal expression profiles for terminal leaves of single and double Bacillus thuringiensis toxin cotton genotypes. J. Econ. Entomol. 94:1589-1593.

Altieri, M.A. 1994. Biodiversity and pest management in Agro-ecosystems. Haworth Press, Binghamton, NY. $185 \mathrm{pp}$.

Balanyá, J., J.M. Oller, R.B. Huey, G.W. Gilchrist, and L. Serra. 2006. Global genetic change tracks global climate warming in Drosophila subobscura. Science 313:1773-1775.

Bale, J.S., G.J. Masters, L.D. Hodkinson, C. Awmack, T.M. Bezemer, V.K. Brown, J. Butterfield, A. Buse, J.C. Coulson, J. Farrar, J.E.G. Good, R. Harrington, S. Hartley, T.H. Jones, R.L. Lindroth, M.C. Press, I. Smyrnioudis, A.D. Watt, and J.B. Whittaker. 2002. Herbivory in global climate change research: direct effects of rising temperature on insect herbivores. Glob. Change. Biol. 8:1-16. 
Benedict, J.H. 2003. Strategies for controlling insect, mite and nematode pests. p. 414-442. In: M.J. Chrispeels, and D.E. Sadava (eds) Plants, genes and crop bio-technology. Jones and Bartlet Publishers. Sudbury, MA.

Biron, D.G., B.S. Landry, J.P. Nénon, D. Coderre, and G. Boivin. 2000. Geographical origin of an introduced pest species, Delia radicum (Diptera: Anthomyiidae), determined by RAPD analysis and egg micromorphology. Bull. Entomol. Res. 90:23-32.

Bokhorst, S., A. Huiskes, P. Convey, P.M. van Bodegom, and R. Aerts. 2008. Climate change effects on soil arthropod communities from the Falkland Islands and the Maritime Antarctic. Soil Biol. Biochem. 40:1547-1556.

Bradshaw, W.E., and C.M. Holzapfel. 2001. Genetic shift in photoperiodic response correlated with global warming. Proc. Natl. Acad. Sci. USA. 96:5565-5569.

Bryant, S.R., J.S. Bale, and C.D. Thomas. 1998. Modification of the triangle method of degree-day accumulation to allow for behavioural thermoregulation in insects. J. Appl. Ecol. 35:921-927.

Butchart, S.H.M., A.J. Stattersfield, L.A. Bennun, H.R. Akcakaya, J.E.M. Baillie, S.N. Stuart, C. Hilton-Taylor, and G.M. Mace. 2005. Using red list indices to measure progress towards the 2010 target and beyond. Philos. Trans. R. Soc. London. 1454:255-268.

Campos-Herrera, R., A. Piedra-Buena, M. Escuer, B. Montalban, and C. Gutierrez. 2010. Effect of seasonality and agricultural practices on occurrence of entomopathogenic nematodes and soil characteristics in La Rioja (Northern Spain). Pedobiologia 53:253-258.

Chen, C.C., and B.A. McCarl. 2001. An investigation of the relationship between pesticide usage and climate change. Clim. Chang. 50:475-487.

Chen, F.J., G. Wu, F. Ge, M.N. Parajulee, and R.B. Shrestha. 2005. Effects of elevated and transgenic Bt cotton on plant chemistry, performance, and feeding of an insect herbivore, the cotton bollworm. Entomol. Exp. Appt. 115(2):341-350.

Chen, S., J. Li, X. Han, and M. Moens. 2003. Effect of temperature on the pathogenicity of entomopathogenic nematodes (Steinernema and Heterorhabditis spp.) to Delia radicum. BioControl 48:713-724.

Ciais, P., M. Reichstein, N. Viovy, A. Granier, J. Ogee, V. Allard, M. Aubinet, N. Buchmann, C. Bernhofer, A. Carrara, F. Chevallier, N. DeNoblet, A.D. Friend, P. Friedlingstein, T. Grünwald, B. Heinesch, P. Keronen, A. Knohl, G. Krinner, D. Loustau, G. Manca, G. Matteucci, F. Miglietta, J.M. Ourcival, D. Papale, K. Pilegaard, S. Rambal, G. Seufert, J.F. Soussana, M.J. Sanz, E.D. Schulze, T Vesala, and R. Valentini. 2005. Europe-wide reduction in primary productivity caused by the heat and drought in 2003. Nature 437:529-533.

Coley, P.D., and A. Markham. 1998. Possible effects of climate change on plant/herbivore interactions in moist tropical forests. Clim. Chang. 39:455-472.

Collier, R.H., S. Finch, K. Phelps, and A.R. Thompson. 1991. Possible impact of global warming on cabbage root fly (Delia radicum) activity in the UK. Ann. Appl. Biol. 118:261-271.

Corlett, T.T., and J.V. LaFrankie, Jr. 1998. Potential impacts of climate change on tropical Asian forests through and influences on phenology. Clim. Chang. 39:439-454.

Coviella, C.E., R.D. Stipanovic, and J.T. Trumble. 2002. Plant allocation to defensive compounds: interactions between elevated $\mathrm{CO}_{2}$ and nitrogen in transgenic cotton plants. J. Exp. Bot. 53:323-331.

Coviella, C.E., and J.T. Trumble. 1999. Effects of elevated atmospheric carbon dioxide on insect-plant interactions. Conserv. Biol. 13:700-712.

Coviella, C.E., and J.T. Trumble. 2000. Effect of elevated atmospheric carbon dioxide on the use of foliar application of Bacillus thuringiensis. BioControl 45:325-336.

Das, D.K., T.P. Trivedi, and C.P. Srivastava. 2001. Simple rule to predict attack of on crops growing in Andhra Pradesh. Indian. J. Anim. Sci. 71:421-423.

Deutsch, C.A., J.J. Tewksbury, R.B. Huey, K.S. Sheldon, C.K. Ghalambor, D.C. Haak, and P.R. Martin. 2008. Impacts of climate warming on terrestrial ectotherms across latitude. Proc. Natl. Acad. Sci. USA. 105:6668-6672.

Dewar, R.C., and A.D. Watt. 1992. Predicted changes in the synchrony of larval emergence and budburst under climatic warming. Oecologia 89:557-559.

Dhaliwal, G.S., R. Arora, and A.K. Dhawan. 2004. Crop losses due to insect pests in Indian agriculture: An update. Indian J. of Ecol. 31:1-7.

Dhaliwal, G.S., V. Jindal, and A.K. Dhawan. 2010. Insect pest problems and crop losses: Changing trends. Indian J. of Ecol. 37:1-7. 
Dhillon, M.K., and H.C. Sharma. 2007. Effect of storage temperature and duration on viability of eggs of Helicoverpa armigera (Lepidoptera: Noctuidae). Bull. Entomol. Res. 97:55-59.

Dhillon, M.K., and H.C. Sharma. 2008. Temperature and Helicoverpa armigera food influence survival and development of the ichneumonid parasitoid, Campoletis chlorideae. Indian J. Plant Prot. 36:240-244.

Dhillon, M.K., and H.C. Sharma. 2009. Temperature influences the performance and effectiveness of field and laboratory strains of the ichneumonid parasitoid, Campoletis chlorideae. BioControl 54:743-750.

Dosdall, L.M. 1994. Evidence for successful overwintering of diamondback moth, Plutella xylostella (L.) (Lepidoptera: Plutellidae), in Alberta. Can. Entomol. 126:183-185.

Ellis, W.N., J.H. Donner, and J.H. Kuchlein. 1997. Recent shifts in phenology of Microlepidoptera related to climatic change (Lepidoptera). Entomolog. Ber. 57:66-72.

Elphinstone, J., and I.K. Toth. 2008. Erwinia chrysanthemi (Pikey spp.)-The facts. Potato Council, Oxford, U.K.

Environment Protection Agency (EPA). 1989. The potential effects of global climate change on the United States. Vol 2: National Studies. Review of the Report to Congress, US Environmental Protection Agency, Washington DC. 261 pp.

Ermel, K., E. Pahlich, and H. Schmutterer. 1986. Azadirachtin content of neem kernel from different geographical locations and its dependence on temperature, relative humidity and light. p.171-184. In: Proceedings of the Third International Neem Conference, Nairobi, Kenya.

Evans, H., N. Straw, and A. Watt. 2002. Climate change: implications for insect pests. Forestry Comm. Bull. 125:99-118.

Fitter, A.H., and R.S. Fitter. 2002. Rapid changes in flowering time in British plants. Science 296:1689-1691.

Forister, M.L., and A.M. Shapiro. 2003. Climatic trends and advancing spring flight of butterflies in lowland California. Glob. Chang. Biol. 9:1130-1135.

Franco, A.M.A., J.K. Hill, C. Kitschke, Y. Collingham, D.B. Roy, R. Fox, B. Huntley, and C.D. Thomas. 2006. Impacts of climate warming and habitat loss on extinctions at species' low-latitude range boundaries. Glob. Chang. Biol. 12:1545-1553.

Freier, B., and H. Triltsch. 1996. Climate chamber experiments and computer simulations on the influence of increasing temperature on wheat-aphid-predator interactions. Asp. Appl. Biol. 45:293-298.

Ganguly, S., and R. Gavas. 2004. Effect of soil moisture on the infectivity of entomopathogenic nematode, Steinernema thermophilum Ganguly \& Singh. Int. J. Nematol. 14:78-80.

Godoy, J.C., R.E. Valera, C. Guedez, L.M. Canizalez, and C. Castillo. 2007. Optimum temperature and humidity determination in germination and sporulation of five Beauveria bassiana isolates. Revista de la Facultad de Agronomía 24:415-425.

Gordo, O., and J.J. Sanz. 2005. Climate change and bird phenology:a long-term study in the Iberian Peninsula. Glob. Chang. Biol. 12:1993-2004.

Gore, A. 2006. An inconvenient truth: The planetary emergency of global warming and what we can do about it. Rodale Publisher, Emmaus, Pennsylvania.

Greenplate, J.T., S.R. Penn, Z. Shappley, M. Oppenhuizen, J. Mann, B. Reich, and J. Osborn. 2000. Bollgard II efficacy: quantification of total lepidopteran activity in a 2-gene product. p. 1041-1043. In: P. Dugger, and D. Richter (eds.) Proceedings, beltwide cotton conference. National Cotton Council of America, Memphis, TN.

Gregory, P.J., S.N. Johnson, A.C. Newton, and J.S.I. Ingram. 2009. Integrating pests and pathogens into the climate change/food security debate. J. Exp. Bot. 60:2827-2838.

Hance, T., J. van Baaren, P. Vernon, and G. Boivin. 2007. Impact of extreme temperatures on parasitoids in a climate change perspective. Annu. Rev. Entomol. 52:107-126.

Harrington, R., R.A. Fleming, and P. Woiwod. 2001. Climate change impacts on insect management and conservation in temperate regions: can they be predicted? Agric. For. Entomol. 3:233-240.

Harrington, R., I. Woiwod, and T. Sparks. 1999. Climate change and trophic interactions. Trends Ecol. Evol. $14: 146-150$.

Hegland, S.J., and L. Boeke. 2006. Relationships between the density and diversity of floral resources and flower visitor activity in a temperate grassland community. Ecol. Entomol. 31:532-538.

Hegland, S.J., A. Nielsen, A. Lázaro, A.L. Bjerknes, and O. Totland. 2009. How does climate warming affect plant-pollinator interactions? Ecol. Lett. 12:184-195.

Heong, K.L., and I. Domingo. 1992. Shifts in predator-prey ranges in response to global warming. Int. Rice. Res. Notes. 17(6):29-30. 
Hickling, R., D.B. Roy, J.K. Hill, R. Fox, and C.D. Thomas. 2006. The distributions of a wide range of taxonomic groups are expanding polewards. Glob. Chang. Biol. 12:450-455.

Hilder, V.A., and D. Boulter. 1999. Genetic engineering of crop plants for insect resistance-a critical review. Crop. Prot. 18:177-191.

Hill, D.S. 1987. Agricultural insects pests of temperate regions and their control. Cambridge University Press, Cambridge, UK. 659 pp.

Hill, M.G., and J.J. Dymock. 1989. Impact of climate change: Agricultural/horticultural systems. DSIR Entomology Division Submission to the New Zealand Climate Change Program. Department of Scientific and Industrial Research, Auckland, New Zealand. 16 pp.

Hódar, J.A., and R. Zamora. 2004. Herbivory and climatic warming: a Mediterranean outbreaking caterpillar attacks a relict boreal pine species. Biodivers. Conserv. 13:493-500.

Inouye, D.W. 2008. Effects of climate change on phenology, frost damage, and floral abundance of montane wildflowers. Ecology 89:353-362.

Inouye, D.W., F. Saavedra, and W. Lee-Yang. 2003. Environmental influences on the phenology and abundance of flowering by Androsace septentrionalis (Primulaceae). Am. J. Bot. 90:905-910.

Isman, M.B. 1997. Neem and other botanical pesticides: Barriers to commercialization. Phytoparasitica 25:339-344.

Jump, A.S., and J. Penuelas. 2005. Running to stand still: adaptation and the response of plants to rapid climate change. Ecol. Lett. 8:1010-1020.

Kaiser, J. 1996. Pests overwhelm Bt cotton crop. Nature 273:423.

Kannan, R., and D.A. James. 2009. Effects of climate change on global diversity: a review of key literature. Trop. Ecol. 50:31-39.

Kaushik, N., B.G. Singh, U.K. Tomar, S.N. Naik, S. Vir, S.S. Bisla, K.K. Sharma, S.K. Banerjee, and P. Thakkar. 2007. Regional and habitat variability in azadirachtin content of Indian neem (Azadirachta indica A. Jusieu). Curr. Sci. 92:1400-1406.

Konvicka, M., M. Maradova, J. Venes, Z. Fric, and P. Kepka. 2003. Uphill shifts in distribution of butterflies in the Czech Republic: effects of changing climate detected on a regional scale. Glob. Ecol. Biogeogr. 12:403-410.

Kranthi, K.R., S. Naidu, C.S. Dhawad, A. Tatwawadi, K. Mate, E. Patil, A.A. Bharose, G.T. Behere, R.M. Wadaskar, and S. Kranthi. 2005. Temporal and intra-plant variability of Cry1Ac expression in Bt-cotton and its influence on the survival of the cotton bollworm, Helicoverpa armigera (Hübner) (Noctuidae: Lepidoptera). Curr. Sci. 89:291-298.

Kremen, C., R.K. Colwell, T.L. Erwin, D.D. Murphy, R.F. Noss, and M.A. Sanjayan. 1993. Terrestrial arthro-

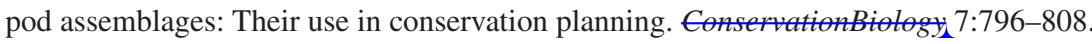

Krieg, A., A. Groner, J. Huber, and M. Matter. 1980. The effect of medium- and long-wave ultraviolet rays (UV-B and UV-A) on insect-pathogenic bacteria and viruses and their influence by UV-protectants. Nachr. Dtsch. Pflanzenschutzd. 32:100-106.

Kung, S.P., R. Gaugler, and H.K. Kaya. 1991. Effects of soil temperature, moisture and relative humidity on entomopathogenic nematode persistence. J. Invertebr. Pathol. 57:242-249.

Lathika, P., and A. Jacob. 1974. Effect of temperature and sunlight on the infectivity of a nuclear polyhedrosis virus of Spodoptera (Boisduval). Curr. Sci. 43:587-588.

Levitan, M. 2003. Climatic factors and increased frequencies of 'southern' chromosome forms in natural populations of Drosophila robusta. Evol. Ecol. Res. 5:597-604.

Li, H., T. Feng, P. Liang, X. Shi, X. Gao, and H.Jiang. 2006. Effect of temperature on toxicity of pyrethroids and endosulfan, activity of mitochondrial $\mathrm{Na}+-\mathrm{K}+$-ATPase and $\mathrm{Ca} 2+-\mathrm{Mg} 2+-\mathrm{ATPase}$ in Chilo suppressalis (Walker) (Lepidoptera: Pyralidae). Pestic. Biochem. Physiol. 86:151-156.

Lindroth, R.L., K.K. Kinney, and C.L. Platz. 1993. Response of deciduous trees to elevated $\mathrm{CO}_{2}$ : productivity, phytochemistry and insect performance. Ecology 74:763-777.

Lydy, M.J., J.B. Belden, and M.A. Ternes. 1999. Effects of temperature on the toxicity of M-parathion, chlorpyrifos, and pentachlorobenzene to Chironomus tentans. Arch. Environ. Contam. Toxicol. 37:542-547.

Maffei, M.E., A. Mithofer, and W. Boland. 2007. Insects feeding on plants: Rapid signals and responses proceeding induction of phytochemical release. Phytochemistry 68:2946-2959.

Maiorano, A., M. Blandino, A. Reyneri, and F. Vanara. 2008 Effects of maize residues on the Fusarium spp. infection and deoxynivalenol (DON) contamination of wheat grain. Crop Prot. 27:182-188. 
McGeoch, M.A. 1998. The selection, testing and application of terrestrial insects as bioindicators. Biol. Rev. Camb. Philos. Soc. 73:181-201.

Menéndez, R., A.G. González-Megías, J.K. Hill, B. Braschler, S.G. Willis, Y. Collingham, R. Fox, D.B. Roy, and C.D. Thomas. 2006. Species richness changes lag behind climate change. Proc. R. Soc. London B. 273:1465-1470.

Menzel, A., T.H. Sparks, N. Estrella, and D.B. Roy. 2006. Altered geographic and temporal variability in phenology in response to climate change. Glob. Ecol. Biogeogr. 15:498-504.

Miller-Rushing, A.J., T. Katsuki, R.B. Primack, Y. Ishii, S.D. Lee, and H. Higuchi. 2007. Impact of global warming on a group of related species and their hybrids: cherry tree (Rosaceae) flowering at Mt. Takao, Japan. Am. J. Bot. 94:1470-1478.

Morgan, D. 1996. Temperature changes and insect pests: a simulation study. Asp. Appl. Biol. 45:277-283.

Myers, N. 1999. The next green revolution: its environmental underpinnings. Curr. Sci. 76:507-513.

Nayak, M.K., and P.J. Collins. 2008. Influence of concentration, temperature and humidity on the toxicity of phosphine to the strongly phosphine-resistant psocid, Liposcelis bostrychophila Badonnel (Psocoptera: Liposcelididae). Pest Manag. Sci. 64:971-976.

Newton, A.C., G. Begg, and J.S. Swanston. 2009. Deployment of diversity for enhanced crop function. Ann. Appl. Biol. 154:309-322.

Parmesan, C. 1996. Climate and species' range. Nature 382:765-766.

Parmesan, C. 2006. Ecological and Evolutionary responses to recent climate change. Annu. Rev. Ecol. Evol. Syst. 37:637-669.

Parmesan, C., and G. Yohe. 2003. A globally coherent fingerprint of climate change impacts across natural systems. Nature 421:37-42.

Parry, M.L. 1990. Climate change and world agriculture. Earthscan, London, UK. 157 pp.

Parry, M.L., and T.R. Carter. 1989. An assessment of the effects of climatic change on agriculture. Clim. Change. 15:95-116.

Paulson, D.R. 2001. Recent Odonata records from southern Florida: effects of global warming? Int. J. Odonatol. 4:57-69.

Peng, S., J. Huang, J.E. Sheehy, R.C. Laza, R.M. Visperas, X. Zhong, G.S. Centeno, G.S. Khush, and K.G. Cassman. 2004. Rice yields decline with higher night temperature from global warming. Proc., Natl. Acad. Sci., USA. 101:9971-9975.

Pinstrup-Andersen, P., and M. Cohen. 2000. Modern biotechnology for food and agriculture: Risks and opportunities for the poor. p. 159-172. In: G.J. Persley and M.M. Lantin (eds.) Agricultural biotechnology and the poor. Consultative Group on International Agricultural Research, Washington DC, USA.

Porter, J.H., M.L. Parry, and T.R. Carter. 1991. The potential effects of climate change on agricultural insect pests. Agric. For. Meteorol. 57:221-240.

Price, M.V., and N.M. Waser. 1998. Effects of experimental warming on plant reproductive phenology in a subalpine meadow. Ecology79:1261-1271.

Price, P.W. 1987. The role of natural enemies in insect populations. p. 287-312. In: P. Barbosa and J.C. Schultz (eds.) Insect outbreaks. Academic Press, San Diego, CA, USA.

Rengasamy, S., and B.S. Parmar. 1995. Azadirachtin A content of seeds of neem ecotypes in relation to the agroecological regions of India. Pest. Res. J. 7:140-148.

Rhoades, D.F. 1985. Offensive-defensive interactions between herbivores and plants: their relevance in herbivore population dynamics and ecological theory. Am. Nat. 125:205-238.

Rodríguez-Trelles, F., and M.A. Rodríguez. 1998. Rapid micro-evolution and loss of chromosomal diversity in Drosophila in response to climate warming. Evol. Ecol. 12:829-838.

Roltsch, W.J., F.G. Zalom, A.J. Strawn, J.F. Strand, and M.J. Pitcairn. 1999. Evaluation of several degree-day estimation methods in California climates. Int. J. Biometeorol. 42:169-176.

Rowntree, P.R. 1990. Estimate of future climatic change over Britain. Weather 45:79-88.

Roy, D.B., and T.H. Sparks. 2000. Phenology of British butterflies and climate change. Glob. Chang. Biol. 6:407-416

Sachs, E.S., J.H. Benedict, D.M. Stelly, J.F. Taylor, D.W. Altman, S.A. Berberich, and S.K. Davis. 1998. Expression and segregation of genes encoding Cry1A insecticidal proteins in cotton. Crop Sci. 38:1-11.

Scherm, H., R.W. Sutherst, R. Harrington, and J.S.I. Ingram. 2000 Global networking for assessment of impacts of global change on plant pests. Environ. Pollut. 108:333-341. 
Sharma, H.C. 2002. Host plant resistance to insects: Principles and practices. p. 37-63. In: B.S. Babu, K.S. Varaprasad, K. Anitha, R.D.V.J. Prasada Rao, and P.S. Chandurkar (eds.) Resources management in plant protection. Vol. 1. Plant Protection Association of India. Rajendarnagar, Hyderabad, Andhra Pradesh, India.

Sharma, H.C. (ed.). 2005. Heliothis/helicoverpa management: Emerging trends and strategies for future research. Science Publishers, USA. 469 pp.

Sharma, H.C. 2009. Biotechnological approaches for pest management and ecological sustainability. CRC Press, New York, NY. 526 pp.

Sharma, H.C. 2010. Effect of climate change on IPM in grain legumes. In: 5th International Food Legumes Research Conference (IFLRC V), and the 7th European Conference on Grain Legumes (AEP VII), 26-30th April 2010, Anatalaya, Turkey.

Sharma, H.C., J.H. Crouch, K.K. Sharma, N. Seetharama, and C.T. Hash. 2002a. Applications of biotechnology for crop improvement: prospects and constraints. Plant Sci. 163:381-395.

Sharma, H.C., M.K. Dhillon, J. Kibuka, and S.Z. Mukuru. 2005. Plant defense responses to sorghum spotted stem borer, Chilo partellus under irrigated and drought conditions. Int. Sorghum and Millets Newsletter. 46:49-52.

Sharma, H.C., and V.F. Lopez. 1994. Influence of panicle size, infestation levels, and environment on genotypic resistance in sorghum to head bug, Calocoris angustatus Lethiery. Entomol. Exp. Appl. 71:101-110.

Sharma, H.C., S.Z. Mukuru, E. Manyasa, and J. Were. 1999. Breakdown of resistance to sorghum midge, Stenodiplosis sorghicola. Euphytica. 109:131-140.

Sharma, H.C., and R. Ortiz. 2000. Transgenics, pest management, and the environment. Curr. Sci. 79:421-437.

Sharma, H.C., K.K. Sharma, and J.H. Crouch. 2004. Genetic engineering of crops for insect control: Effectiveness and strategies for gene deployment. CRC Crit. Rev. Plant. Sci. 23:47-72.

Sharma, H.C., C.P. Srivastava, C. Durairaj, and C.L.L. Gowda. 2010. Pest management in grain legumes and climate change. p.115-140. In: S.S. Yadav, D.L. McNeil, R. Redden, and S.A. Patil (eds.) Climate change and management of cool season grain legume crops. Springer Science + Business Media, Dordrecht, The Netherlands.

Sharma, H.C., D.J. Sullivan, and V.S. Bhatnagar. 2002b. Population dynamics of the Oriental armyworm, Mythimna separata (Walker) (Lepidoptera: Noctuidae) in South-Central India. Crop Prot. 21:721-732.

Sharma, H.C., G. Venkateswarulu, and A. Sharma. 2003. Environmental factors influence the expression of resistance to sorghum midge, Stenodiplosis sorghicola. Euphytica. 130:365-375.

Sharma, H.C., and F. Waliyar. 2003. Vegetational diversity, arthropod response, and pest management. p. 66-88. In: F. Waliyar, L. Collette, and P.E. Kenmore (eds.) Beyond the gene horizon: Sustaining agricultural productivity and enhancing livelihoods through optimization of crop and crop-associated diversity with emphasis on semi-arid tropical agro-ecosystems. International Crops Research Institute for the SemiArid Tropics (ICRISAT), Patancheru, Andhra Pradesh, India.

Smith, C.M. 2005. Plant resistance to arthropods - Molecular and conventional approaches. Springer Verlag, Dordrecht, The Netherlands. 423 pp.

Soman, P., K.F. Nwanze, D.R. Butler, and Y.V.R. Reddy. 1994. Leaf surface wetness in sorghum and resistance to shoot fly, Atherigena secata: role of soil and plant water potentials. Ann. Appl. Biol. 124:97-108.

Sparks, T.H., E.P. Jeffree, and C.E. Jeffree. 2000. An examination of the relationship between flowering times and temperature at the national scale using long-term phenological records from the UK. Int. J. Biometereol. 44:82-87.

Stefanescu, C., J. Peñuelas, and I. Filella. 2003. Effects of climatic change on the phenology of butterflies in the northwest Mediterranean Basin. Glob. Chang. Biol. 9:1494-1506.

Steffan-Dewenter, I., and S. Schiele. 2008. Do resources or natural enemies drive bee population dynamics in fragmented habitats. Ecology 89:1375-1387.

Stireman, J.O. III, L.A. Dyer, D.H. Janzen, M.S. Singer, J.T. Lill, R.J. Marquis, R.E. Ricklefs, G.L. Gentry, W. Hallwachs, P.D. Coley, J.A. Barone, H.F. Greeney, H. Connahs, P. Barbosa, H.C. Morais, and I.R. Diniz. 2005. Climatic unpredictability and parasitism of caterpillars: implications of global warming. Proc., Natl. Acad. Sci. USA. 102:17384-17387.

Stone, A.C., C.A. Gehring, and T.G. T.G. Whitham. 2010. Drought negatively affects communities on a foundation tree: growth rings predict diversity. Oekologia164:751-761.

Sutherst, R.W. 1991. Pest risk analysis and the greenhouse effect. Rev. Agric. Entomol. 79:1177-1187. 
Talbot Trotter III, R., N.S. Cobb, and T.G. Whitham. 2008. Arthropod community diversity and trophic structure: a comparison between extremes of plant stress. Ecol. Entomol. 33:1-11.

Taylor, N., and G.A. Matthews. 1986. Effect of different adjuvants on the rainfastness of bendiocarb applied to Brussels sprout plants. Crop Prot. 5:250-253.

Thomas, C.D., E.J. Bodsworth, R.J. Wilson, A.D. Simmons, Z.G. Davies, M. Musche, and L. Conradt. 2001. Ecological and evolutionary processes at expanding range margins. Nature 411:577-581.

Thomas, C.D., A. Cameron, R.E. Green, M. Bakkenes, L.J. Beaumont, Y.C. Collingham, B.F.N. Erasmus, M. Ferreira de Siqueira, A. Grainger, L. Hannah, L. Hughes, B. Huntley, A.S. van Jaarsveld, G.F. Midgley, L. Miles, M.A. Ortega-Huerta, A.T. Peterson, O.L. Phillips, and S.E. Williams. 2004. Extinction risk from climate change. Nature 427:145-148.

Thomas, C.D., A.M.A. Franco, and J.K. Hill. 2006. Ranges retractions and extinction in the face of climate warming. Trends. Ecol. Evol. 21:415-416.

Thomas, C.D., M.C. Singer, M.C., and D. Boughton. 1996. Catastrophic extinction of population sources in a butterfly metapopulation. Am. Nat. 148:957-975.

Thompson, S.R., R.I. Brandenburg, and J.J. Arends. 2006. Impact of moisture and UV degradation on Beauveria bassiana (Balsamo) Vuillemin conidial viability in turfgrass. Biol. Control. 39:401-407.

Uddin, M.A., and N. Ara. 2006. Temperature effect on the toxicity of six insecticides against red flour beetle, Tribolium castaneum (Herbst.). J. Life Earth Sci. 1:49-52.

Umina, P.A., A.R. Weeks, M.R. Kearney, S.W. McKechnie, and A.A. Hoffmann. 2005. A rapid shift in a classic clinal pattern in Drosophila reflecting climate change. Science 308:691-693.

UNEP-WCMC. 2000. Global biodiversity: Earths living resources in the 21st century; World Conservation Press, Cambridge, UK.

UNFCCC (United Nations Framework Convention on Climate Change). 2007. Climate change: Impacts, vulnerabilities and adaptation in developing Countries. Climate Change Secretariat, INFCCC, Bonn, Germany. 64 pp.

van Frankenhuyzen, K. 1994. Effect of temperature on the pathogenesis of Bacillus thuringiensis Berliner in larvae of the spruce budworm, Choristoneura fumiferana Clem. (Lepidoptera: Tortricidae). Can. Entomol. 126:1061-1065.

Verhaar, M.A., T. Hijwegen, and J.C. Zadoks. 1998. Selection of Verticillium lecanii isolates with high potential for biocontrol of cucumber powdery mildew by means of components analysis at different humidity regimes. Biocontrol Sci. Technol. 8:465-477.

Visser, M.E., and C. Both. 2005. Shifts in phenology due to global climate change: the need for a yardstick. Proc. R. Soc. London B 272:2561-2569.

Visser, M.E., C. Both, and M.M. Lamberchts. 2004. Global climate change leads to mistimed avian reproduction. Adv. Ecol. Res. 35:89-110.

Walstad, J.D., R.F. Anderson, and W.J. Stambauch. 1970. Effects of environmental conditions on two species of muscardine fungi (Beauveria bassiana and Metarhizium anisopliae). J. Invertebr. Pathol. 16:221-226.

Wang, X.Y., and Z.R. Shen. 2007. Potency of some novel insecticides at various environmental temperatures on Myzus persicae. Phytoparasitica 35:414-422.

Ward, N.L., and G.J. Masters. 2007. Linking climate change and species invasion: an illustration using insect herbivores. Glob. Chang. Biol. 13:1605-1615.

Warwick, F.S. 1985. Effects of pH on the toxicity and uptake of [14C] lindane in the midge, Chironomus riparius. Ecotoxicol. Environ. Saf.10:202-208.

Waser, N.M., L. Chittka, M.V. Price, N.M. Williams, and J. Ollerton. 1996. Generalization in pollination systems, and why it matters. Ecology 77:1043-1060.

White, T.C.R. 1984. The abundance of invertebrate herbivores in relation to the availability of nitrogen in stressed food plants. Oecologia 63:90-105.

Willis, C.G., B. Ruhfel, R.B. Primack, A.J. Miller-Rushing, and C.C. Davis. 2008. Phylogenetic patterns of species loss in Thoreau's woods are driven by climate change. Proc., Natl. Acad. Sci., USA. 105:17029-17033.

Wilson, R.J., D. Gutiérrez, J. Gutiérrez, D. Martínez, R. Aguado, and V.J. Montserrat. 2005. Changes to the elevational limits and extent of species ranges associated with climate change. Ecol. Lett. 8:1138-1146.

Wilson, R.J., D. Gutiérrez, J. Gutiérrez, and V.J. Montserrat. 2007. An elevational shift in butterfly species richness and composition accompanying recent climate change. Glob. Chang. Biol. 13:1873-1887. 
Xannepuccia, A.D., A. Ciccihino, A. Escalante, A. Navaro, and J.P. Isaach. 2009. Differential responses of marsh arthropods to rainfall-induced habitat loss. Zool. Stud. 48:173-183.

Yamamura, K., and K. Kiritani. 1998. A simple method to estimate the potential increase in the number of generations under global warming in temperate zones. Appl. Entomol. Zool. 33:289-298.

Yencho, G.C., M.B. Cohen, and P.F. Byrne. 2000. Applications of tagging and mapping insect resistance loci in plants. Annu. Rev. Entomol. 45:393-422.

Young, A.M. 1982. Population biology of tropical insects. Plenum Press, New York, NY. 511 pp.

Zhou, X., R. Harrington, I.P. Woiwod, J.N. Perry, J.S. Bale, and S.J. Clark. 1995. Effects of temperature on aphid phenology. Glob. Chang. Biol. 1:303-313.

Zvereva, E.L., and M.V. Kozlov. 2010. Responses of terrestrial arthropods to air pollution: a meta-analysis. Environ. Sci. Pollut. Res. Int. 17:297-311. 